\title{
Contesting English Hegemony in Zambian Education System: Causes and Effects
}

\author{
Pamela Muma Musonda*, David Sani Mwanza \\ The University of Zambia, Zambia
}

\author{
*Corresponding Authors: Pamela Muma Musonda, The University of Zambia, Zambia
}

\begin{abstract}
In Zambia, English is the official language and a language of instruction from Grade 5 going upwards. It had been a determining subject for any pupil to proceed to Grade 10. However, a policy was developed to remove English as a qualifying subject for Grade 9 examinations. The purpose of this study was to establish why English was censured from its mandatory position and what effect the removal has had on the teaching and learning attitudes of teachers and pupils. Thus, the objectives were to: establish reasons why English was removed as a mandatory passing subject at Grade 9 level; and to analyse the attitudes of teachers of English and pupils towards government's removal of English as a mandatory passing subject at Grade 9. The study used a qualitative design and employed a case study strategy of inquiry. The data collection techniques used in the study were interviews and focus group discussions. Purposive sampling technique was used to come up with a total of 72 respondents of which 4 were standards officers, 3 school managers from 3 schools, 9 teachers and 48 pupils from the same schools. Respondents also included 4 former pupils and 4 parents. Data was analysed using the inductive thematic analysis. The findings of the study established that the removal of English as a mandatory passing subject at Grade 9 was because of pupils' low literacy levels and low proficiency levels in English. The other reason was that government wanted to grant opportunity to grade nine pupils access to senior secondary education. The findings showed that after English was removed as a mandatory passing subject, most of the teachers of English and pupils held negative attitudes towards teaching/learning English while a few others held positive ones. The study recorded 3 participants who were in support of having English as a mandatory passing subject while others were not. The study also established that motivation played a major role in the teaching and learning of English. The study recommended translanguaging as an alternative pedagogy especially for classes whose English proficiency is low.
\end{abstract}

Keywords: Stakeholders, English, Mandatory, Motivation

\section{BACKGROUND}

English is the official language, widely used in government, in broadcasting and in education. In Zambia the most important official language is undoubtedly English (Ohannessian and Kashoki 1978). Zambia is one of the countries that were colonized by Britain. English, being a former colonial language was declared the national language at independence in 1964. Zambia has a rich linguistic heritage with over 70 local languages and dialects, among which seven have official status: Bemba, Nyanja, Lozi, Tonga, Kaonde, Luvale and Lunda. In a study done by Simwinga (2007) on the history of English in Zambia, it is stated that between 1964 and 2004, English was regarded as the sole official language at national level on the assumption that as a neutral language its use would not trigger ethnic emotions which would work against national unity and national development. Later, in the 1970's, it was acknowledged that the use of English as a sole language of classroom instruction was proving a disadvantage to most of the children whose only contact with the language was inside the classroom. Hence, in the 1990s, use of community languages as medium of instruction from Grades One to Four was recommended. Zambia now uses English language as a medium of instruction from Grade 5 to tertiary education.

Elsliden (2017) stated that English is the international language used for wider communication to an extent that no other language can be compared. Elsliden also stated that in many areas, English is the tool of communication between people from different countries as well as between individuals from the same country. Nishanthi (2018) emphasized the importance of learning English, that it is the international common tongue. It is used in education. Nishanthi also stated that knowing how to read English allows access to billions of pages of information which may not be otherwise available. The 
paper brought in the reason of travel and business, stating that one can travel around the globe if they have a good understanding and communication in English. It was also mentioned that English is easy to learn.

English has had a higher status in the Zambia's education system. Banda (2012) explained in his paper that today, English is the most important language as far as social mobility is concerned. It enjoys unchallenged social prestige, has high practical values and it alone holds the key to jobs in the formal sector of the economy. English was a mandatory passing subject for a Grade 9 pupil to qualify to Grade 10 but with the coming of the new policy in 2009, it had been waived off and any pupil who passes in any six subjects will have made it to Grade 10 . Government reviewed the policy of having English as a mandatory passing subject at Grade 9 in 2009 when it abolished the cut off point system which had English as a requirement among the passing subjects. A pupil only needed to obtain a full school certificate regardless of which subjects they passed in, as long as they passed in six subjects. Banda and Mwanza (2017) point out that while previously, English was a mandatory passing subject for one to qualify to Grade 10, the new 'policy' has made English as an equal subject to any other subject and is no longer a mandatory passing subject. Banda and Mwanza further stated that for the first time, the unchallenged position of English at secondary school had not only been challenged but questioned. The Basic Education Sector Analysis Report of 2012 disclosed the use of English as the official medium of instruction beginning at Grade 5 up to tertiary. Janneke (2007) gave out the allocation of subjects per week of which English was allocated 7 to 9 periods. This shows how much attention English had received in Zambian schools.

On 11th February, 2009, the policy of cut-off point abolition was passed. This was the policy which in turn waived English as a mandatory passing subject. The former Minister of Education, Honorable Geoffrey Lungwangwa announced this in a ministerial statement to parliament:

"Government has abolished the cut off-point system to select grade nine pupils to grade ten and replaced it with a full school certification as a criterion to qualify to grade ten. A total of 110,798 pupils obtained full grade certificates in last year's examinations and have consequently qualified to grade ten."

All the candidates who obtained full certificates during their Grade 9 examinations in 2008 had since qualified to Grade 10. This decision of selecting candidates based on their full certificate was aimed at allowing more pupils proceed to Grade 10 (Ministerial Statement to Parliament, 2009) This means that any pupil who fulfils the requirements for a full certificate at Grade 9 level, despite the grades and marks they obtain and regardless of which subject they pass in, are allowed to proceed to Grade 10. This system, therefore, enables a lot of pupils to enter Grade 10 regardless of the marks attained in the English language.

This radical change in the examination progression which eludes English invites questions. Firstly, what are the reasons which led to the removal of English as a mandatory passing subject? Secondly, what do teachers and pupils think of the removal and how has this changed their perception and approach to the teaching and learning of English language subject? Thus, this study was conducted to establish the rationale behind the contestation of English hegemony and the implications this contest has on teachers and learners.

\section{Statement Of The Problem}

In Zambia, English is the official language and a language of instruction from Grade 5 going upwards (The Basic Education Sector Analysis Report of 2012). English had been a determining subject for a Grade 9 pupil to proceed to Grade 10. However, it was removed as a qualifying subject for Grade 9 examinations in 2009. The research problem therefore is why was English removed from its hitherto unchallenged status and how has this affected the way teachers and pupils approach the teaching and learning of English respectively.

\section{RESEARCH OBJECTIVES}

This study's research objectives were to;

a. establish reasons why English was removed as a mandatory passing subject at Grade 9 level

b. investigate the attitudes of teachers of English and pupils towards government's removal of English as a mandatory passing subject at Grade 9 


\section{THEORETICAL FRAMEWORK}

This study adopts Critical Discourse analysis theory to frame and analyse the study. Critical Discourse Analysis is a type of discourse analytical research that primarily studies the way social power abuse, dominance and inequality are enacted, reproduced and resisted by text and talk in the social and political context (Van Dijk (1998). It emerged from 'critical linguistics' developed at the University of East Anglia by Roger Fowler and fellow scholars in the 1970s. According to Fairclough (1995), CDA argues that social practice and linguistic practice constitute one another and focuses also on investigating how societal power relations are established and reinforced through language use. Van Dijk (1993) explains that power involves control by one group over the other, while dominance refers to hegemonic existence where the minds of the dominated are influenced in a way that they accept dominance and act in the interest of the powerful out of their own free will. In this case, policy makers have power over institutions of learning and they take dominance of what takes place in the classrooms. Teachers, pupils and other stakeholders only follow what they are told to by government which uses its power to effect policies, like the one under discussion, in institutions like schools. Government has power to change policies according to what it considers best for schools. In this study, CDA, was used to analyse the influence of government's policy of waiving English as a mandatory passing subject over what happens during the process of learning English subject in class. It also analysed the attitudes of both teachers and pupils towards the subject following the policy change. This also affects what exists between the government and what goes on in the classroom. CDA was used in this study to analyse the power and control that government has over teachers and pupils in line with education policies. This theory was used to analyse teachers' and pupils' views and attitudes towards the English waiver. Since the concept of power in CDA focuses on the weak, controlled and discriminated against, in the classroom it focuses on the teachers and pupils. It chooses the perspectives of those who suffer and critically analyses the language use of those in power and responsible for the existence of inequalities and have the means and opportunity to improve conditions (Wodak 2002). That is why the views of teachers and pupils are crucial to understand how they position themselves within the power relationship involving English.

CDA was used in this study to analyse the power between the classroom and the influence that government has over it. CDA considers the relationships of power, dominance, resistance and discrimination which characterise teaching and the entire education system. More specifically, it focuses on the ways discourse structures enact, confirm, legitimate, reproduce or challenge relations of power and dominance in society (van Dijk, 1993).

Van Dijk (1993), splits up the issue of discursive power into three basic aspects for CDA-research; firstly, how (more) powerful groups control public discourse. In line with this study, government, which is the (more) powerful group sets up policies through policy makers to control what goes on in the classroom. Secondly, how discourse controls the mind and action of the less powerful groups and what social consequences are there such as social inequalities. The consequences of government's power over the classroom (less powerful group), is that it affects attitudes of teachers and pupils towards the teaching and learning of English language subject. The third one is how dominated groups discursively challenge or resist power. Teachers and pupils develop negative attitudes towards the English subject teaching and learning and end up yielding poor results at Grade 9 end of year examinations. This happens so because they know that English language is no longer a compulsory passing subject at Grade 9 level and that whether pupils pass it or fail, they would still proceed to Grade 10. Teachers also have control over their pupils; they can control their pupils' attitudes by encouraging them to study hard so as to pass their examinations. This can be done by encouraging pupils of the benefits that would come out of passing English subject. For example, it is a mandatory passing subject at Grade 12 and a mandatory requirement at tertiary level.

In conclusion, there are many stakeholders in the education system but the ones that are mostly affected by the power relations are the policy makers, the teachers and pupils who are found in school and the classroom at large. All these stakeholders should be involved in decision making if power is to be distributed equally.

\section{Methods And Materials}

This study adopted the qualitative research design. This was the right design because it enabled us to collect in-depth data from the participants who were all purposively sampled in order to collect the 
required data. This study's sample was drawn from Ministry of Education offices; national, provincial and district where four officers were interviewed. Three public schools were sampled; urban, peri urban and rural. From each of the three sampled schools, 1 school manager and 3 teachers of English were interviewed. From the same schools, 2 focus group discussions with 8 pupils in each group were done with the Grade 9 and 12 pupils respectively. More interviews were done with 4 former pupils who sat for their Grade 9 examinations before English was removed as a mandatory passing subject, 4 Parents for both categories of pupils were also interviewed. A total of 72 participants were purposively sampled. This study used semi-structured interview guides and focus group discussion guides. Face to face interviews were done with the standards officers, school managers, teachers of English, parents to both current and former pupils, as well as former pupils who wrote their Grade 9 examinations before the policy of waiving English as a mandatory passing subject. Kombo and Tromp (2006) asserted that semi-structured interviews are flexible because they consist of both open and close-ended questions. The flexibility of the semi-structured interviews helped the researcher to rephrase questions and probe respondents further so as to get clearer responses. A focus group discussion is usually composed of 6 to 8 individuals who share certain characteristics that are relevant to the study (Kombo and Tromp, 2006). The focus group discussions were used to collect data from the current pupils. The data collected from the current pupils was on their views towards learning English subject at Grade 9.

\section{Presentation Of Findings}

The findings are presented under the two objectives. Following thematisation of findings, sub themes are used under the first objective to present the reasons why English was removed as a mandatory passing subject at grade 9 level.

\subsection{Reasons Why English Was Removed As A Mandatory Passing Subject At Grade 9}

The first objective was to find out reasons why English was removed as a mandatory passing subject at Grade 9 level. The researcher analysed data from interviews that were done with the standards officers, school managers and teachers of English. From the analysed data, the following reasons were given: low literacy levels, access to senior secondary education, low pupil proficiency in English, and political expedience. The reasons were presented as follows:

\subsubsection{Low Literacy Levels}

Respondents talked to revealed that there had been a problem in the Zambian education system concerning literacy levels. They mentioned that literacy levels had been measured in a standardized manner using the national surveys which had been conducted in the country since 1999 starting from Grade 5 level. They stated that English was removed as a mandatory passing subject at Grade 9 level because of the low literacy levels in Zambia. The following was what they had to say;

One of the big problems that our education system has had, has to do with low literacy levels because English falls within the literacy aspect of learning achievement. So, one of the major components of the national assessments is to assess literacy achievement levels by grade 5 learners and the agreement was that assessment be done after 2 years. Results of this national assessment, at national level, show that our learners have consistently underperformed in terms of literacy acquisition (SO $\mathbf{O}$ )

Most learners did not know how to read and write (SO 2)

In addition to the aforementioned reason, one school administrator and two teachers stated their experiences in their school/classrooms over their pupils' low literacy levels in the following verbatims;

\section{Most learners did not break through even up to Grade 9 level (AD C)}

You know, pupils came raw from primary school. Teachers were made to start teaching them how to read and write at Grade $9(\boldsymbol{T r} \mathbf{3 A})$

Leaners' vocabulary was bad. They did not know how to read or write correct spellings $(\operatorname{Tr} 9 C)$ 


\subsubsection{Access to senior secondary education}

Respondents disclosed another reason as to why English was removed as a mandatory passing subject. It was stated that pupils needed not to be judged on the basis of English.

This is shown in the following verbatims;

Every year when exams are released by the Examinations Council of Zambia, the ministry's interest is in how many of those learners got grade 9 certificates, it's not in which subject ( $\mathbf{S} \boldsymbol{O} \mathbf{1})$

The system was sweeping the streets so as to give them access to education. We are practicing the swallow everything even if the stomach is full. Access to senior secondary schooling was another reason for removing English as a compulsory passing subject because some of our learners would do well in 6 or 7 subjects but as long as they failed English, they could not get a Grade 9 certificate (SO 2)

\subsubsection{Low pupil proficiency in English subject}

Some respondents mentioned that Grade 9 pupils had challenges with the semantics and syntax of the English language. They could not understand the subject matter and it resulted in them failing or having low marks in the subject. The following verbatims explain more;

The issue of tying English to certification needed to be reconsidered to say we are throwing away potential entrants to senior secondary just because they did not perform well in English at Grade 9: pupils should not be judged on the basis of English. We should not disadvantage them when maybe they are not academically privileged to understand the syntax and the semantics which may be what made them not to pass English (SO 1)

The reason partly was that many children were failing English language. English language has grammatical rules that are followed which pupils are not conversant with despite being taught by the teachers who are trained to teach English (SO 2)

One respondent brought out the issue of political expedience. The respondent mentioned that politicians had interest in the number of pupils who proceeded to Grade 10. Therefore, they loosened some benchmarks to accommodate learners who did not pass in English subject. The following verbatim shows this;

So, after they sat in parliament and passed that, it was not just that children were failing, no, they wanted to actually win political mileage as Zambian politicians. That particular year they saw that a lot of children would remain in the streets because whoever had not passed in English despite the fact that they had 6 subjects as long as they didn't have English, they could not proceed to Grade 10. They were afraid of discrediting government by the huge numbers of Grade 9 pupils who failed. Hence, they swept the streets by trying to loosen the benchmarks for Grade 9 pupils to proceed to Grade 10. English language was not necessarily removed but it remained in suspense because as long as they have it or not, they would still go to Grade 10. Meaning a child can even decide to say even if I remove English, even if I don't sit for it, I would still pass in other subjects ( $\mathbf{S} \boldsymbol{O} 2$ )

6.2. Views of Teachers of English and Pupils About How the Removal of English as a Mandatory Passing Subject Has Affected Their Teaching and Learning of English

The second objective was to investigate the attitudes of teachers of English and pupils towards government's removal of English as a mandatory passing subject at Grade 9. Teachers and pupils explained how this had affected their attitudes towards the teaching/learning of English as a subject in both positive and negative ways. It was important to investigate their attitudes because attitudes play an important role in whatever a person is doing, in this case, teachers and pupils. Face to face interviews were done with teachers of English and focus group discussions were done with the pupils.

\subsubsection{Teachers' Attitudes Towards English Language Teaching as a Result of English Removal as a Mandatory Passing Subject at Grade Nine Level}

Teachers mentioned that they had positive attitudes towards English subject teaching. They stated that their positive attitudes were because of the rewards that came after pupils had passed in their subject. 
They also stated that they worked hard because they knew that if they did not, then pupils' performance in other subjects would be affected. These and more reasons of their positive attitudes were given in the following verbatims;

As teachers, we are putting in our efforts but learners don't mind whether they pass or not, teachers are trying. As a teacher we have a heart to teach learners whether the children are interested or not. We try to motivate them and talk to them one on one, those that are serious learners get motivated and improve, the selected few but most of them do not take interest. I'm sometimes motivated to work hard so that I can get a prize when they beam the results and say my learners have passed with a 100\% (Tr 1A)

I attend to pupils as a group as well as individually when they have challenges in English. Sometimes they come with questions which I help them answer. I don't want my pupils to fail even if English is not a passing subject anymore $(\operatorname{Tr} 8 C)$

Despite teachers having positive attitudes towards the teaching of English subject, other teachers stated their negative attitudes and what caused them to have such attitudes. Some teachers talked to stated that they just taught for routine purposes. They did not work as hard as they used to work before the REMPS because they knew that whatever the case, pupils would still go to Grade 10 even without passing English. They would teach English but not with the extra effort which they were putting in previously, before the REMPS. The following verbatims show the various responses of teachers regarding their negative attitudes towards teaching English;

Well, we don't check pupils' books effectively. When we mark them in class after teaching then that's the end (Tr $3 A$ )

I don't give much work to learners because of over enrollment ( $\operatorname{Tr} \mathbf{4 B}$ )

I don't have time to help pupils individually because there are a lot of pupils to attend to and other classes would be waiting for me. When I'm done teaching, I start preparing lessons for the following day (Tr $5 \boldsymbol{B})$

Sometimes we just use any language we are comfortable with instead of English $(\operatorname{Tr} 7 C)$

Since I knew about this policy, my desire to put in a lot of effort in teaching my subject has been destroyed somehow (Tr 9C)

Some teachers blamed their negative attitudes on their pupils. They stated that their positive attitudes changed to negative ones because of the negative attitudes of their pupils. They mentioned that their pupils did not pay much attention to passing English or following teachers to ask on topics they were not clear on.

My attitude has also changed because of the learners' attitude which is negative $(\operatorname{Tr} 2 A)$

Teaching English is so discouraging because of the learners who didn't do well at primary school. They came raw, we have to start teaching them what they were supposed to learn at primary. It's very discouraging ( $\boldsymbol{T r} \mathbf{6 B})$

Most of the learners don't understand English so I usually just use Bemba to explain things. I'm discouraged to use English on them because they can't even express themselves in English ( $\boldsymbol{T r} 8 \mathrm{C})$

No matter how much you try, the attitude of learners is discouraging. There are those that take interest and work well with the teacher. Otherwise, the attitude of learners has been very negative $(\boldsymbol{T r} \mathbf{9 C})$

6.2.2. Pupils' Attitudes Towards English Language Learning as a Result of English Removal as a Mandatory Passing Subject at Grade Nine Level

According to the information that pupils gave out during the focus group discussions, they mentioned that they would not stop paying attention to English subject because of it being removed as a 
mandatory passing subject. The participants talked to, stated that they would still continue to work hard in English because they would like to pass it at Grade 9 as well as at Grade 12. Different reasons were given by pupils as to why they would want to pass in English. The pupils talked to stated that they were working hard now because they would want to learn how to write application letters well and be able to speak out properly during interviews. They also mentioned that passing English would help them when they go to study abroad. These and more reasons were given. Consider the following verbatims;

I'm working hard in English because if I don't work hard it can be difficult when I want to get a job. It will be difficult for you if you don't pass English. If you go somewhere else, in other countries where they don't speak your language, it will be difficult for you. For example, if you want to find an address. If you go somewhere else in other countries where they don't speak your language, it will be difficult for you. So, I'm working hard so that I pass my exam (CP $2 A)$

I try my best to pass in English because it helps me in understanding other subjects because teachers teach us in English (CP 3A)

We are studying hard so that we can pass our exams. You can't go to college if there's no English $(\boldsymbol{C P} \mathbf{4 B})$

We are working hard in English because we will need it to write application letters (CP $5 B)$

Contrary, other pupils mentioned that they did not study hard in English subject because they knew that they would still go to Grade 10 without passing it. They mentioned how the REMPS had made them not to study hard or pay attention to English because they knew they would not need to pass it mandatorily at the end of their academic year.

We stop concentrating because we know it's not a passing subject (CP 1A)

Pupils have a lot to contribute in class but because they can't speak in English, they can't say anything $(\boldsymbol{C P} \mathbf{1 B})$

It's okay madam even if we don't pass it because we still use English when learning these other subjects (CP 1C)

However, one pupil mentioned how other pupils' attitudes have been, knowing that they would not have to pass in English mandatorily to proceed to Grade 10. The following was what the pupil had to say;

Some of my friends don't study English because they know they will still go to Grade 10 but they'll have difficulties in Grade 10. Some know to speak but can't write and they'll fail to write application letters and CVs (CP 3A)

Standards officers, school managers, and teachers of English language made observations on the attitudes of learners towards the subject. The aforementioned participants revealed that they observed some negative attitudes in their learners. Consider the following verbatims;

Pupils have a negative attitude and at the end of the day they do not attach seriousness to learning. They know that even if they don't pass English, they'll still go to Grade 10: hence the negativity. Teachers can prepare but some pupils don't even write, some pupils wait for others to write then they copy: I've come across a good number of such (SO 2)

They no longer care because they know that even if they don't pass English, they would still proceed to Grade 10 (SO 3)

This has affected learners in working hard, they are not working as hard as they used to sometime back. Learners have taken English as a by the way thing such that they don't even study in groups, I haven't seen them do that, they don't even consider it as a study subject, they don't even do tuitions in English now but before this policy they used to do tuitions $(\operatorname{Tr} 1 A)$

Pupils are no longer attaching any importance to English subject ( $\operatorname{Tr} 3 A)$ 
Pupils have a negative attitude because they know they don't have to pass it. Those who didn't break through before coming to Grade 9 do not even pay attention to English because they know that they do not have to pass it (Tr $4 B$ )

The attitude of learners has been very negative. Out of $100 \%$ of learners, just $5 \%$ of learners will come to ask for assistance with what they don't understand: they have a very bad attitude. Grade nines just read once in a while, even discussions, according to my observation $(\boldsymbol{T r} 2 A)$

The teacher added on to say that the policy had made Grade 9 learners lazy because they did not mind their grades in the subject. The following was what the teacher said;

Learners have become lazy because they know that even if they have $40 \%$ in six subjects and whether they have English or not they'd still proceed to Grade 10 ( Tr 2A)

One teacher mentioned how their Grade 9 learners' attitudes towards English subject had also affected their attitudes at Grade 10, especially those who did not pass in English subject at Grade 9. Consider the following verbatim;

\section{Grade 10 learners have a negative attitude because of not doing well at Grade 9 (Tr 6B)}

\section{Discussion OF FINDINGS}

The discussion of findings is being done under the two broad themes informed by objectives. However, the identified sub themes have also been used to present the data.

\subsection{Reasons Why English Was Removed as a Mandatory Passing Subject at Grade 9}

The government of Zambia removed English language as a mandatory passing subject at Grade 9 level on 11th February, 2009 through a statement to parliament by former Minister of Education Honorable Geoffrey Lungwangwa. Government has power to set up policies through policy makers to control what goes on in the classroom. Policy makers have power over institutions of learning and take dominance over what takes place in the classrooms. Teachers, pupils and other stakeholders only follow what is laid down for them by government which uses its power to effect policies. Van Dijk (1993) explains that power involves control by one group over the other. English was removed as a mandatory passing subject for various reasons which were revealed by different stakeholders who were interviewed. Below is a discussion of the reasons why English was removed:

\subsubsection{Low literacy levels}

Standards officers disclosed that literacy levels in Zambia had been measured in a standardised manner using the national surveys which had been conducted since 1999 from Grade 5 level. They revealed that the national assessment showed that learners consistently underperformed in terms of literacy acquisition nationwide. In agreement, Mulenga (2012) states that pupils in Zambia are not able to read and write at the desirable levels, including some that had supposedly broken through by the end of Grade 2. Teachers revealed that they were made to teach spellings and simple words to pupils who supposedly had broken through to literacy. Findings from some Standards Officers, school managers and teachers of English interviewed revealed that most of the pupils did not actually breakthrough to literacy from lower grades up to junior secondary level. The Government of Zambia removed English language as a mandatory passing subject at Grade 9 because of these low literacy levels. This was in tandem with Mwambazi (2011) who states that pupils were not able to read according to their grade level. These findings show that poor literacy levels are not just at primary level but extended to secondary school at Grade 9 level.

Nevertheless, findings revealed that there was an assumption by the Ministry of Education that in the next three years of senior secondary schooling, pupils would possibly upscale their competences in the English language. However, teachers of English revealed that pupils who did not perform well at junior secondary school did not perform well at senior secondary school as well. The Ministry of Education's assumption was in contradiction with what was revealed in the findings. Further, the Minister of General Education revealed in a ministerial statement about the 2020 Grade 9 External and GCE Examinations that performance in English Language continues to be poor as the subject 
poses a challenge to the candidates. What this means is that pupils face problems at Grade 9 and continue with the challenges throughout senior secondary school.

\subsubsection{Access to Senior Secondary Education}

The other reason for the removal of English as a mandatory passing subject was that the Government of Zambia wanted to grant opportunity to Grade 9 pupils to access senior secondary education. The removal of English as a mandatory passing subject came about after the abolition of cut-off point system. The abolition of the cut-off point system was aimed at ensuring that all Grade 9 certificate holders proceeded to Grade 10. A lot of pupils proceeded to Grade 10 who previously would not have had the opportunity, thereby drastically reducing the number of drop-outs after Grade 9. Miti L. (2017) states that the cut-off mark system was a tragedy and robbed children from under privileged backgrounds access to education. In addition, Moonga et al (2018) also state that both the Movement for Multiparty Democracy (MMD) and the Patriotic Front (PF) parties ensured that there was access to education for all at all levels of education. It appears that the removal of cut off points was not adequate. English was seen as the major obstacle to this. However, while the removal of English has increased the number of pupils going to Grade 10, performance in the subject has remained poor. In 2009, the Zambian parliament disclosed that in 2008, 110,798 Grade 9 candidates obtained full certificates out of the 228,107 who sat for the examination. Consequently, all Grade 9 pupils who had full certificates, with or without passing English qualified to Grade 10.

It was revealed in the findings that government removed English as a mandatory passing subject because it realised that it was throwing away potential senior secondary school entrants by putting English language as a compulsory passing subject at Grade 9 level. More findings revealed that government was practicing the 'swallow it all even if the stomach is full' by sweeping the streets to give pupils access to senior secondary education. This was in tandem with The Global Initiative on Out-of-School Children (2014) which states that it had put a strategy for increasing access to senior secondary (Grade 10) which was to abolish the Grade 9 cut-off point system in Zambia. While access has been achieved, the implication is that there is over enrollment in schools. Teacher pupil ratio is poor and teaching materials are inadequate. It would have been expected that the removal of English should have corresponded with construction of more schools and furniture to cope with large numbers.

\subsubsection{Political Expedience}

Political expedience was also brought out as being one of the reasons for the removal of English as a mandatory passing subject at Grade 9. Findings revealed that politicians had interest in the number of pupils who proceeded to Grade 10. It was revealed that politicians loosened some benchmarks to accommodate all the pupils even those who did not pass in English subject. Participants revealed that in that particular year (2009), politicians observed that many pupils who had written their Grade 9 examinations in 2008 would remain on the streets. Therefore, they made English to be equal to other subjects. Consequently, the interest of government through the Ministry of General Education was in how many of those learners passed in six subjects and not a particular subject they passed in. Findings from stakeholders interviewed revealed that 'sweeping the streets' system had a negative effect at Grade 9 performance in English and a triple effect at Grade 12 where English was required mandatorily. Participants revealed that the government was just pushing the pupils forward without taking note of pupil's strengths or weaknesses. They further revealed that government was interested in granting access to education for all pupils whether they passed in English or not. Findings suggest that government or politicians measure their governance and success through the success of their citizens. Therefore, removing English as a mandatory passing subject was to aid the 'success rate' of the children.

\subsubsection{Low Pupil Proficiency in English}

Low pupil proficiency in English subject was another reason for the removal of English as a mandatory passing subject that was revealed by the stakeholders interviewed. Participants revealed various ways that pupils displayed their low proficiency in English subject. It was revealed that Grade 9 pupils had challenges with the semantics and syntax of the English language. Teachers also revealed that they had to teach pupils in Grade 9 how to read and write. They also revealed that pupils could not understand the subject matter, hence their failure in English at Grade 9. It was revealed further 
that most of the pupils did not pay much attention to the subject because they knew that they did not have to pass English to proceed to senior secondary school. In agreement, Ama (2019) states that students do not take their studies seriously. They often think that the same English they speak at home or on the street is the same they will write in their exams and they do not try to learn new words. Poor proficiency can be attributed to the sociolinguistic backgrounds of the pupils where they speak Zambian languages at home but mandatorily use English at school.

\subsection{Attitudes of Teachers and Pupils Towards Government's Removal of English as a Mandatory Passing Subject at Grade Nine}

The second objective was to investigate the attitudes of teachers of English and pupils towards government's removal of English as a mandatory passing subject at Grade 9. In the face-to-face interviews with teachers of English and focus group discussions with pupils, findings revealed how the removal of English had affected their teaching/learning of English language. Below is the discussion on attitudes of teachers and pupils respectively:

Findings revealed that some teachers held positive attitudes towards English teaching even after its removal as a mandatory passing subject because of the rewards that followed after pupils had passed in English. These rewards were expected after the end of year examinations results where teachers and pupils would be given prizes during Teachers' Day/Open and Prize giving Day respectively. This means that teachers were instrumentally motivated. This was in tandem with Parijat et al. (2014) who state that instrumentality is the perception of an employee of the probability that performance will lead to organisational rewards or outcomes. Findings revealed that the motivation that teachers had to teach English was because of the rewards they received. In agreement, Mwanza (2017) states that attitudes of teachers often directly impact the implementation of a curriculum.

On the contrary, findings revealed that most of the teachers of English held negative attitudes towards the teaching of English after its removal as a mandatory passing subject. According to findings collected from teachers, they revealed that their negative attitudes affected their teaching and pupils' performance negatively. Teachers further revealed that they taught for routine purposes. Most of the teachers interviewed revealed that they did not work as hard as they used to when English was a mandatory passing subject. Findings also revealed that teachers' efforts to work hard in teaching English were destroyed when they knew that it was no longer a mandatory passing subject at Grade 9. In agreement, Mwanza (2017) states that teachers' attitudes are key to the success or failure of policy implementation. In addition, Kapansa (2019) states that poor attitudes by teachers are a barrier to pupil learning. Thus, the findings contradict $\mathrm{Wu}$ and Lee (2017) who found that there was no relationship between teacher attitudes towards the policy and pupil performance.

The findings also show blame games between teachers and pupils. Teachers stated that their negative attitudes were as a result of pupils' negative attitudes toward English subject. They stated that they were mostly discouraged because their pupils did not know how to read or write and that very few took interest to work well with teachers. However, Mwanza (2016) advises that it is the teachers' attitudes that superimpose pupils' attitudes. In addition, Gajalakshimi (2013) states that it is the job of teachers to enhance pupils' attitudes to learning English through the use of more classroom activities that resonate with pupils' language interests and aspirations. The above authors assert that it was the teachers' duties to ensuring that learners developed positive attitudes and that learning took place in class.

Findings revealed that the removal of English as a mandatory passing subject had an implication on what went on in classrooms in relation to the number of pupils per class. Teachers revealed that they could not give the amount of work that was supposed to be given to their pupils due to over enrollment. They could not manage marking their pupils' books or to go through individual pupils' work due to the many numbers of pupils in their classrooms. However, Dixon (2016) asserts that with the increased enrollment of learners, teachers need to be prepared to meet their students' needs. This means that teachers should not render themselves vulnerable in the face of classroom challenges but instead, be creative and agile to handle teaching challenges.

Regarding pupils, some of them revealed that they held positive attitudes towards learning English. Findings revealed that they were still working hard in English even if it was not a mandatory passing subject. Findings further revealed that the positive attitudes held by some pupils towards learning 
English was because they wished to pass in the subject. These pupils did not only want to pass English in order to proceed to senior secondary school but also to access tertiary education. Findings further revealed that the pupils who held positive attitudes towards English learning were motivated to do so because they wished to study further both in and outside Zambia. These findings are in tandem with Abubakar et al. (2017) who state that the students' motivation and preferences are among the fundamental factors for effective and useful learning and achievement. In view of the Expectancy Theory, these pupils knew that passing English would reward them in future. Thus, they worked hard for future rewards.

However, other pupils disclosed their own negative attitudes towards learning English through focus group discussions. Findings revealed that some pupils stopped paying attention to English subject because it was not a mandatory passing subject. They also stated that they stopped paying attention because they did not have to pass it to proceed to Grade 10. Unlike those pupils who held positive attitudes, these pupils did not consider the future gains of mastering English. They did not consider that they would need it to pass Grade 12 and that English still remained the only medium of instruction in tertiary institutions in Zambia. This lack of knowledge made them focus on the Grade 9 level. It is therefore important that teachers of English and guidance and counselling teachers advise pupils.

Findings further revealed that pupils' classroom performance in English was not good because of their negative attitudes towards learning it. In line with this finding, Almed (2015) mentions that students' attitude towards English learning might hinder their learning.

From a motivational point of view, findings revealed that pupils were negatively affected if teachers were not motivated to teach. Pupils were also negatively affected if teachers were not awarding them. Pupils expected to be awarded during Honors' Day as well as in their respective classes by way of praising them. Abubakar (2017) states that to encourage low motivated learners, external rewards are needed to convince them to participate in activities. This asserts that teachers hold the strongest keys to pupils' attitudes towards their subjects. Thus, schools may need to consider the reward system to motivate learners in English at Grade 9.

In addition, Mlay (2010) states that for students to perform well in examinations they need to be motivated by teachers and be willing to study conscientiously. Teachers and other stakeholders need to understand their pupils' negative attitudes and shape them into positive ones as Viet (2017) adds that better understanding of students' attitude would help language teaching programmes, school managers and educators to develop strategies to improved student's learning outcomes. It is therefore possible to argue that pupils are motivated to learn when their teachers motivate them. In another study, Abubakar et al. (2017) state that when teachers and pupils are motivated, they get successful and achieve their set goals.

Findings further revealed that the effects of Grade 9 pupils' negative attitudes towards the removal of English as a mandatory passing subject affected their performance. This was so because pupils knew that it was not mandatory for them to pass English to get into senior secondary education. It was revealed that the negative effect of the removal of English went up to tertiary education level. This finding is in tandem with Sa'ad and Usman (2014) who state that causes of poor performance in English language among students was due to negative attitudes of students toward English language. It was also revealed that pupils who did not pass in English at junior secondary level did not have the motivation to work hard at senior secondary level even with the teachers' efforts and help. In line with this, Primadi et al. (2015) state that students' positive attitude may be caused by their motivation. They also state that teachers should respect and carefully investigate their students' feelings to maintain the positive attitudes towards English and English language learning. In this view, it can be deduced that government should consider the long-term effects of this policy because it may negatively affect the social mobility of learners both in tertiary education and in the end at work.

\section{CONCLUSION}

The study has shown that English hegemony has been contested and its position has been negotiated at grade nine. In this case, what was the gate way to senior secondary school has been removed and all subjects have been equalized. By this policy decision, the Zambian Ministry of General Education has removed the coloniality which the English language has served for years since the colonization of 
Africa. Although English has remained the mandatory passing subject at grade 12, its removal at grade 9 is seen as a positive step towards the decolonization of Zambian education.

\section{REFERENCES}

[1] Abu-Snoubar, T.K. (2017). An Evaluation of EL Students' Attitudes Towards English Language Learning in Terms of Several Variables. Al-Balqa Applied University

[2] Al-Sobhi, B. Rashid, S. and Abdullah, A.N. (2018). Arab ESL Secondary School Students' Attitude Toward English Spelling and Writing. Malaysia

[3] Anderson, E. (2019). Teachers' Attitudes Affect Students. A Study of Swedish Primary School Teachers' Attitudes Towards CLIL. Sweden: University of Gavle

[4] Arif, N. (2015). Removing English as a Compulsory Subject rom Primary Schools on the 2013 Curriculum Based on Teachers' Opinion. Indonesia: Jambi University

[5] Arif, N. (2013). Teachers' Opinion about Removing English as a Compulsory Subject in the Primary School Level. Indonesia: Jambi University

[6] Banda, D (2012), Empowering or disabling: the evaluation of the Primary Reading Programme (PRP) in Zambia. Köln: Lambert Publishing Company- Germany

[7] Banda, D. and Simwinga, J. (2018). Language-In-Education Policy in Zambia: Policy and other Dynamics. Lusaka: UNZA Press

[8] Banda F. and Mwanza, D.S. (2017). Language In-Education Policy and Linguistic Diversity in Zambia: An Explanation to Low Literacy Levels among Primary School Pupils. In Banja, M.K. (ed). Selected readings in education, 109-130. Lusaka: University of Zambia Press.

[9] Banda, F. and Mwanza, D.S. (2017). Contesting English Hegemony in Zambia's Education System: Trial and Error? Powerpoint Presentation presented at the English Department Conference in Botswana.

[10] Borg, W.R. \& Gall, M.D. (1979). Education Research: An Introduction. London: Longman

[11] Borg, W. R. (1963). Education Research: An Introduction. London: Longman

[12] Borja, C. (2016). Attitude in English and Competence of Students at Integrated Refinery Petro-chemical Complex (IRPCT). Thailand: Technological College

[13] Bryman, A. (2004). Social Research (2nd Ed.). New York: Oxford University Press

[14] Cohen, L., Manion, L. \& Morrison, K. (2007). Research Methods in Education. New York: Routledge

[15] Cohen, L., Manion, L. and Morrison, K. (2000). Research Methods in Education (5th Edition). London: Routledge Falmer

[16] Creswell, J.W. (2012). Educational Research: Planning, Conducting and Evaluating Quantitative and Qualitative Research. U.S.A: Pearson Education, Inc.

[17] Creswell, J.W., Vicki L., Clark P. (2007). Designing and Conducting Mixed Method Research. Thousand Oaks, Calif: SAGE Publications

[18] Feustein, M.T. (1986). Partners in Education: Evaluation Development and Community

[19] Programmes with Participants. Oxford: MacMillan Education

[20] Gajalakshmi (2013). High School Students' Attitude Towards Learning English Language. International Journal of Scientific and Research Publications, Volume 3, Issue 9, September 2013: ISSN 2250-3153

[21] Goldman, T. (2019). English Language Teaching in Zambia: A Cultural Analysis. Zambia

[22] Green, J. and Thorogood, N. (2004). Qualitative Methods for Health Research. London: SAGE Publications

[23] Hsu, (2009). Compulsory Pass in English will be Good. United Kingdom: Kirby College

[24] Kanchele, M.R. (2013). Implications of Abolition of the Grade 9 Cut-off Points in Rural High Schools: The Case of Mwandi High School in Sesheke District of the Western Province of Zambia. Zambia: The University of Zambia

[25] Kelly, M. J. (1999). The origins and development of education in Zambia: From pre-colonial times to 1996: a book of notes and readings. Lusaka, Zambia: Image Publishers

[26] Kombo, D. and Tromp, D. (2006). Proposal and Thesis Writing: An Introduction. Nairobi: Pauline's Publications Africa

[27] Kulkarni, R. (2016). Attitude Towards English Language of Standard Students. Dharwad: Karnatak University

[28] Lee, J. and Heinz, M. (2016). English Language Learning Strategies Reported by Advanced Language Learners. Korea: Hankuk University of Foreign Studies

[29] Marten, L. and Kula, N.C (2007). Zambia: 'One Zambia, One Nation, Many Languages'. Zambia: Spi Publisher Services 
[30] Ministerial Statement to Parliament (2009). Govt has Abolished Cut-off Point System for Grade 9 Exams. Accessed on 15/05/19 at https://www.lusakatimes.com

[31] Miti, L. (2017). Grade $7 \& 9$ Cut-off Point System is a Tragedy, a Crime against Children. Accessed on 17/02/2020 at http://www.lusakatimes.com

[32] Ministry of Education, (2007). Education Sector National Implementation Framework 2008-2010. Lusaka: Government of the Republic of Zambia

[33] Mwanza, D.S. (2017). Implications of Teachers' Attitudes towards Unofficial Language on English Language in Multilingual Zambia. Journal of Language Studies, 1 (1): 101-124

[34] Mwanza, D.S. (2016). A Critical Reflection of Eclecticism in the Teaching of English Grammar at Selected Zambian Secondary School. Unpublished PhD Thesis. South Africa: University of Western Cape

[35] Nishanthi, R. (2018). The Importance of Learning English in Today World. India: Bharathidasan University

[36] Orodho, A.J. (2003). Essential of educational and Social Sciences Research Method.

[37] Nairobi: Masola Publishers

[38] Palinkas, L.A. et al. (2013). Purposeful Sampling for Qualitative Data Collection and Analysis in Mixed Method. Implementation Research. Los Angeles: University of California

[39] Ritchie, J. and Lewis, J. (2003). Qualitative Research Practice: A Guide or Social Science Students and Researchers. London: SAGE Publications

[40] Shaw, W.D. (1981). English for Cross-cultural Communication. Asian Student attitudes Towards English. In Smith L.E (eds) English for Cross-cultural Communication. London: Palgrave Macmillan

[41] Simwinga, J. (2007). Forty Years of Language Policy Formulation in Zambia: Greater Prospects for Mother Tongue Education? in Chandaka, Y., Phiri, B.J. and Chabatama, C.M. (ed). Zambia: Forty Years after Independence 1964-2004. Department of History: University of Zambia ISBN 9982-9918-2-5 pp 172-187

[42] Smadi, O.M. and Al-Ghazo, A. (2013). Johdanian Teachers' Attitudes Towards Foreign Language Teaching and their Relationship to These Teachers' Classroom Practices. Jordan: Ajloun National University

[43] Zedilla, W.E. (2016). Removing English as Compulsory Subject rom Primary Schools on the 2013 Curriculum in Indonesia. Indonesia

\section{AUTHORS' BIOGRAPHY}

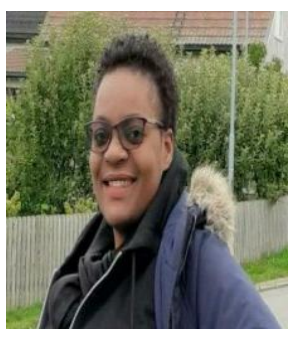

Pamela Muma Musonda, has just completed her Master of Education in Applied Linguistics Degree at the University of Zambia. She is also a teacher of English and Literature in English at Gibeon Adventist Secondary School in Northern Zambia. Her area of research include English teaching methods, teacher education and power relations in the school.

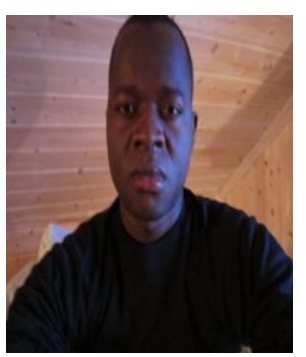

David Sani Mwanza, holds PhD in Linguistics from University of the Western Cape. He is a senior lecturer at the University of Zambia where he trains teachers of English and Zambian languages. His areas of research include Multilingual Education, English Teaching Methods, Teacher Education, Translanguaging, eclectic pedagogy, school power relations and identity in the school and the school community.

Citation: Pamela Muma Musonda \& David Sani Mwanza. "Contesting English Hegemony in Zambian Education System: Causes and Effects" International Journal on Studies in English Language and Literature (IJSELL), vol 9, no. 3, 2021, pp. 1-13. doi: https://doi.org/10.20431/2347-3134.0903001.

Copyright: (C) 2021 Authors. This is an open-access article distributed under the terms of the Creative Commons Attribution License, which permits unrestricted use, distribution, and reproduction in any medium, provided the original author and source are credited. 